\title{
Effect of Quaternary Ammonium Salts with Fluorine Atoms on Selected Weed Species
}

\author{
Robert Biczak $^{1} \cdot$ Barbara Pawłowska $^{1} \cdot$ Maciej Płatkowski $^{2} \cdot$ Michał Stręk $^{2}$. \\ Arkadiusz Telesiński ${ }^{2}$
}

Received: 23 June 2016 / Accepted: 24 January 2017 / Published online: 14 February 2017

(C) The Author(s) 2017. This article is published with open access at Springerlink.com

\begin{abstract}
This study investigated the effects of four structurally different quaternary ammonium salts (QASs), i.e., tetrabutylammonium tetrafluoroborate $[\mathrm{TBA}]\left[\mathrm{BF}_{4}\right]$, tetrahexylammonium tetrafluoroborate $[\mathrm{THA}]\left[\mathrm{BF}_{4}\right]$, tetrabutylammonium hexafluorophosphate $[\mathrm{TBA}]\left[\mathrm{PF}_{6}\right]$, and tetrahexylammonium hexafluorophosphate $[\mathrm{THA}]\left[\mathrm{PF}_{6}\right]$, on the growth and development of three weed species: gallant soldier (Galinsoga parviflora Cav.), white goosefoot (Chenopodium album L.) and common sorrel (Rumex acetosa L.). The examined compounds were applied in the form of foliar spraying and soil application. Strong herbicidal properties of the examined compounds were demonstrated in case of their soil application. Growth inhibition of plant shoots and roots was greater with soil application than with foliar treatment. The strongest herbicidal activity of compounds was demonstrated with $[\mathrm{TBA}]\left[\mathrm{BF}_{4}\right]$ have demonstrated [TBA] $\left[\mathrm{BF}_{4}\right]$ and $[\mathrm{TBA}]\left[\mathrm{PF}_{6}\right]$ applied to the soil, while $[\mathrm{THA}]\left[\mathrm{BF}_{4}\right]$ demonstrated the weakest herbicidal action. The increased concentration of applied QASs caused a decrease in the assimilation pigments, change in dry weight content and inhibition of length of shoots and roots.
\end{abstract}

Robert Biczak

r.biczak@ajd.czest.pl

1 Department of Biochemistry and Ecotoxicology, The Faculty of Mathematics and Natural Sciences, Jan Długosz University in Częstochowa, Armii Krajowej Av. 13/15, 42-200 Częstochowa, Poland

2 Department of Plant Physiology and Biochemistry, Faculty of Environmental Management and Agriculture, West Pomeranian University of Technology in Szczecin, Juliusza Słowackiego st. 17, 71-434 Szczecin, Poland
Keywords Phytotoxicity · Dry weight · Chlorophyll · Inhibition of plant growth and roots

In recent years, much importance has been ascribed to the discovery of environmentally safe herbicides in crop protection (Praczyk and Skrzypczak 2004; Travlos et al. 2014). With this in mind, research teams from around the world have been looking for new compounds that exhibit desirable herbicidal properties and are concurrently harmless to other organisms. An example of a new and promising class of compounds with herbicidal properties is that of the herbicidal ionic liquids (HILs) (Pernak et al. 2016; Niemczak et al. 2015).

Quaternary ammonium salts (QASs) are a group of compounds within the class that have demonstrated numerous desirable properties, including wetting, emulsifying, dispersing, antistatic and preservative properties. Moreover, they have also demonstrated biological activity (e.g., algaecidal, fungicidal, and bactericidal), resulting in a wide range of practical applications (Grabińska-Sota 2004). Representatives of this group of compounds include tetrabutylammonium tetrafluoroborate $[\mathrm{TBA}]\left[\mathrm{BF}_{4}\right]$, tetrahexylammonium tetrafluoroborate $[\mathrm{THA}]\left[\mathrm{BF}_{4}\right]$, tetrabutylammonium hexafluorophosphate $[\mathrm{TBA}]\left[\mathrm{PF}_{6}\right]$, and tetrahexylammonium hexafluorophosphate $[\mathrm{THA}]\left[\mathrm{PF}_{6}\right]$. These compounds are insoluble in water, but well soluble in organic solvents. They are relatively inexpensive compared to other QASs or ionic liquids (ILs). The use of compounds that are already commercially available for testing as potential herbicides eliminates the costs associated with the synthesis and purification of new compounds.

This study examined the effects of [TBA] $\left[\mathrm{BF}_{4}\right]$, [THA] $\left[\mathrm{BF}_{4}\right]$, $[\mathrm{TBA}]\left[\mathrm{PF}_{6}\right]$ and $[\mathrm{THA}]\left[\mathrm{PF}_{6}\right]$ on the growth and development of three commonly occurring weed species: 
G. parviflora, C. album and $R$. acetosa. The new groups of biologically active compounds which would exhibit selective or total herbicidal properties, concurrently being nontoxic for the environment, have been searched during this study. Such compounds could be used in the future as alternatives to currently used herbicides, or as replacements for those that have been withdrawn from use.

\section{Materials and Methods}

The test compounds tetrabutylammonium tetrafluoroborate $[\mathrm{TBA}]\left[\mathrm{BF}_{4}\right](99 \%$ purity), tetrahexylammonium tetrafluoroborate $[\mathrm{THA}]\left[\mathrm{BF}_{4}\right]$ ( $\geq 97 \%$ purity), tetrabutylammonium hexafluorophosphate $[\mathrm{TBA}]\left[\mathrm{PF}_{6}\right](98 \%$ purity) and tetrahexylammonium hexafluorophosphate [THA] $\left[\mathrm{PF}_{6}\right]$ ( $\geq 97 \%$ purity) used in the study were purchased from Sigma-Aldrich Chemical Co (Poznań, PL).

A pot experiment for the determination of potential phytotoxicity of the QASs was carried out in the vegetation hall of the Department of Biochemistry and Ecotoxicology at Jan Długosz University in Częstochowa, PL. The same weights of seeds were sown to plastic pots with a diameter of $90 \mathrm{~mm}$ containing $250 \mathrm{~g}$ of soil. The soil used in the experiment was light loam with dissolved matter content of approx. $10 \%$, organic carbon content of $0.9 \%$ and $\mathrm{pH}$ equal to 6.0. Three weeks after emergence, the plants were sprayed with solutions of the examined compounds. Weighed amounts of each QAS were dissolved in $10 \mathrm{~mL}$ of a water-methanol mixture to yield $0.5 \%, 1.0 \%$ and $2.0 \%$ concentrations. Then, $2 \mathrm{~mL}$ of the solution with a given concentration was collected and used for spraying leaves of plants growing in the pots. The controls were also prepared in an analogous manner, and they were sprayed with an aqueous-alcoholic solution, but without QAS addition. Thus, the amounts of QASs administered to the surface were equal to the amounts of active substances contained in commercial herbicides. This allowed to a certain extent for the comparison of phytotoxicity of the studied QASs with substances available in the market.

Throughout the testing period (21 days), constant substrate moisture content at the level required for the plants (70\% field water capacity), a constant temperature of $20 \pm 2{ }^{\circ} \mathrm{C}$ and a light intensity of $160 \mu \mathrm{mol} \mathrm{m} \mathrm{m}^{-2} \mathrm{~s}^{-1}$ were maintained in the system of $16 \mathrm{~h} /$ day and $8 \mathrm{~h} /$ night.

The tests concerning determination of an effect of salts applied to soil on selected weed species were conducted for 28 days under the same conditions as in the case of foliar examinations. The examined compounds were added to the soil (incorporation) and weed seeds of $G$. parviflora, $C$. album and $R$. acetosa, sown on such prepared ground. The concentrations for each QAS compound were 100, 400 and $700 \mathrm{mg} \mathrm{kg}^{-1}$ of soil dry weight. The analytically weighed amounts of QASs were dissolved in $10 \mathrm{~mL}$ acetone, and then $50 \mathrm{~g}$ of quartz sand was added, rinsing the dish with pure acetone several times. In order to obtain the same QAS concentration from each substrate volume, after the open air evaporation of acetone, the weighed amount of quartz sand was carefully mixed with $200 \mathrm{~g}$ of soil. For each concentration, three independent samples were prepared. Identical weights of seeds of the studied plant species were immediately sown into the substrates thus prepared.

Phytotoxicity of the QAS compounds was determined by measuring dry weight content of the weed leaves, shoot length and root length. Shoot and root lengths were measured as described by Wang et al. (2009). Shoot length can be defined as the length from the tip of the longest leaf to the base of culms, and root length can be defined as the length from the tip of the longest root to the root-shoot junction. Inhibition ratio was calculated as (length in control group-length in treatment group) $x 100 \% /$ length control group. Results were expressed as shoot height and root length inhibition in comparison to control.

Photosynthetic pigments content was determined according to the method reported by Oren et al. (1993). Fresh leaves $(0.2 \mathrm{~g})$ homogenized in $20 \mathrm{~mL} 80 \%$ acetone using a mortar and pestle were placed into a centrifuge tube. The extraction was carried out in darkness for $24 \mathrm{~h}$, and the extracts were centrifuged for $10 \mathrm{~min}$. The supernatants were used for determination of the content of chlorophyll $a$ and $b$, and carotenoids by measuring absorbance at 470, 647 and $664 \mathrm{~nm}$, respectively. Pigment content was expressed as $\mathrm{mg} \mathrm{g}^{-1}$ dry weight (DW).

Plant dry weights were measured as described by Kowalska (2004). One gram fresh weight samples of the plants were dried to constant weight at a temperature of $105^{\circ} \mathrm{C}$. The dry weight content was expressed as $\mathrm{g} \mathrm{g}^{-1}$ fresh weight (FW).

The results were analyzed statistically using a statistical software package Statistica v. 12.0 (Statsoft, Inc., Krakow, $\mathrm{PL})$. The data from three measurements $(\mathrm{n}=3)$ were analyzed using one-way ANOVA. Homogeneous groups were calculated using Tukey's test with $p<0.05$. The results were expressed as the mean \pm standard deviation.

\section{Results and Discussion}

The results showed that the examined QASs exhibited herbicidal properties. The strongest herbicidal activity was observed for all compounds after the salts were introduced into the soil. The use of $[\mathrm{TBA}]\left[\mathrm{BF}_{4}\right],[\mathrm{THA}]\left[\mathrm{BF}_{4}\right]$, $[\mathrm{TBA}]\left[\mathrm{PF}_{6}\right]$ and $[\mathrm{THA}]\left[\mathrm{PF}_{6}\right]$ in the form of soil application caused a marked inhibition of the growth of plants and their roots, increasing with increased concentration of 
QAS application. C. album was the most sensitive to QASs among the species tested. None of $C$. album seeds germinated following application of [TBA] $\left[\mathrm{BF}_{4}\right]$ and $[\mathrm{TBA}]\left[\mathrm{PF}_{6}\right]$ (Fig. 1a, b). In turn, foliar spraying caused an inhibition in the growth of aerial parts and roots of $C$. album. Observed changes in the cases of QAS soil applications were positively correlated with applied concentrations of these compounds. Spraying of $R$. acetosa leaves with solutions of $[\mathrm{TBA}]\left[\mathrm{BF}_{4}\right]$, [THA] $\left[\mathrm{BF}_{4}\right]$, $[\mathrm{TBA}]\left[\mathrm{PF}_{6}\right]$ resulted in an inhibition of aerial parts growth, depending on compound concentration, but no such effect on the length of the roots of this species was noted (less than $10 \%$ or no inhibition). The most resistant plant to foliar treatment was G. parviflora, for which only slight growth inhibition was observed following spray applications of $1 \%$ and $2 \%$ solutions of [TBA] $\left[\mathrm{BF}_{4}\right]$ and $2 \%$ solution of [THA] $\left[\mathrm{PF}_{6}\right]$. In the cases of other concentrations of these QASs and after an application of $[\mathrm{THA}]\left[\mathrm{BF}_{4}\right]$ and $[\mathrm{TBA}]\left[\mathrm{PF}_{6}\right]$, no inhibition in aerial parts growth of G. parviflora plants and their roots was observed (Fig. 1c, d).

Biczak et al. (2015) reported extreme phytotoxic effects in common radish and spring barley when tetrafluoroborates with the alkilimidazole cation were added to soil. Additionally this impact depended on the length of carbon

(a)
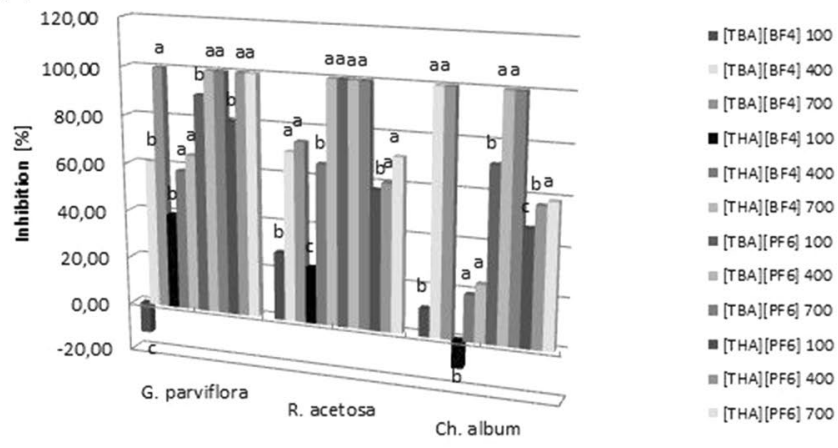

(c)

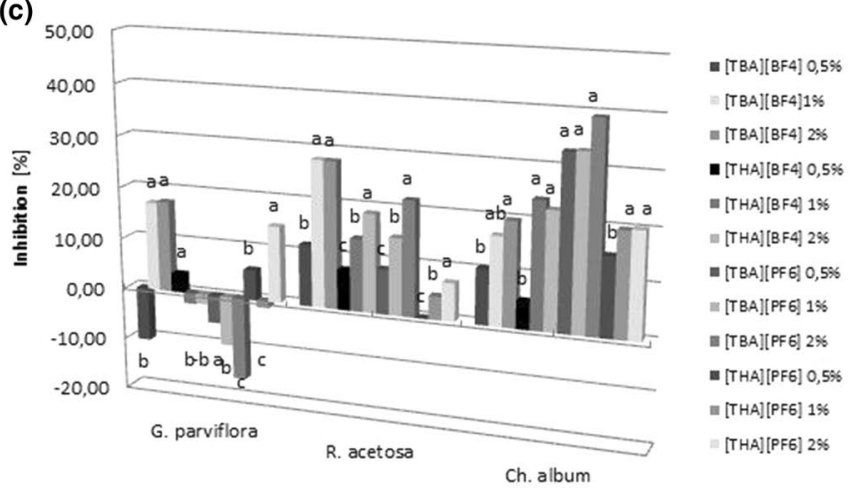

Fig. 1 Inhibition of growth plant (a) and root (b) G. parviflora, $R$. acetosa and $C$. album exposed to [TBA] $\left[\mathrm{BF}_{4}\right],[\mathrm{THA}]\left[\mathrm{BF}_{4}\right]$, [TBA] $\left[\mathrm{PF}_{6}\right]$ and $[\mathrm{THA}]\left[\mathrm{PF}_{6}\right]$ in soil and inhibition of growth plant $(\mathbf{c})$ and chain in the substituent. Chiral ionic liquids used by these authors in the form of foliar spraying of $G$. parviflora, $C$. album and $R$. acetosa plants also demonstrated an inhibitory effect of these salts on the growth and development of the examined weed species. Salts containing $\mathrm{PF}_{6}{ }^{-}$anion in their structure are also considered in the literature as compounds exhibiting high toxicity to plants due to the fact that their hydrolysis produces fluoride ions which are toxic and highly undesirable in the environment (Biczak et al. 2014; Cho et al. 2008; Matzke et al. 2007). Telesiński and Śnioszek (2009) found that fluoride effects on plants concern, inter alia, the negative impact of this element on assimilation processes and photosynthesis, which in turn leads to plant growth inhibition. These phenomena result from the destructive effect of fluorine on chloroplasts. The strong effects of the examined QAS compounds when added to soil may be related to the fact that soil is the environment for plant development, from which they collect water and nutrients, as well as toxic chemicals (Chapman et al. 2012). Peric et al. (2014), Biczak (2016) and Pawłowska and Biczak (2016) reported that the presence of harmful substances in the soil can also cause an inhibition in seed germination, and even complete blockage of their germination capacity.
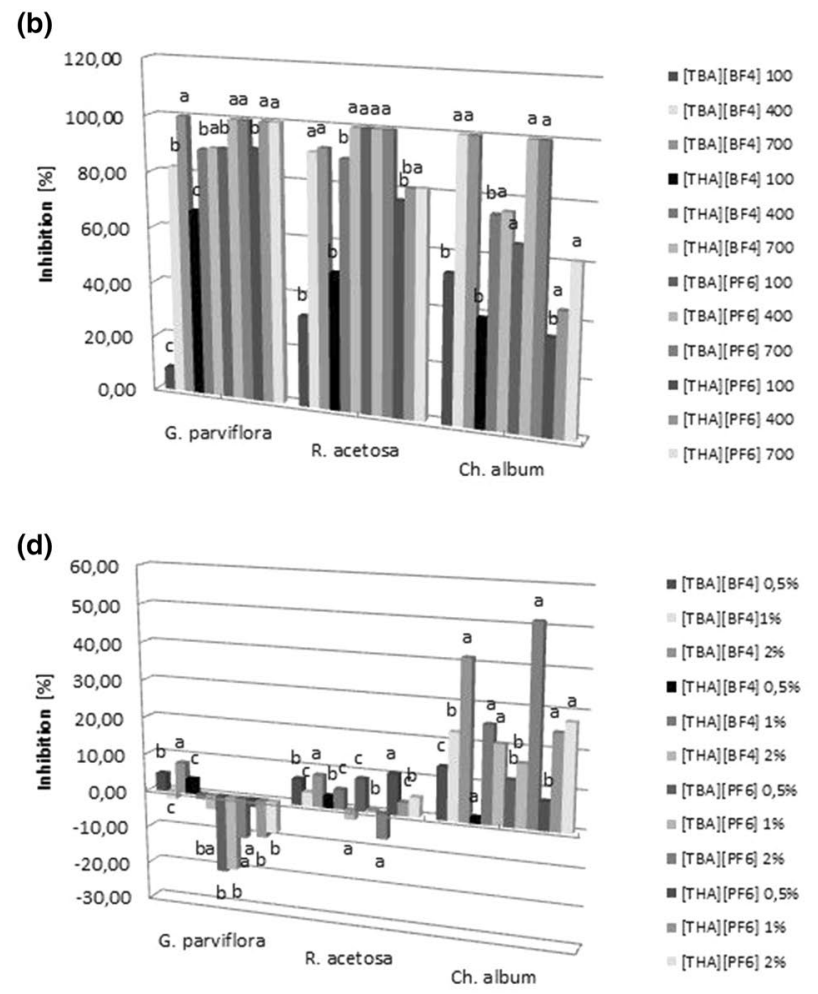

root (d) weeds exposed to QASs applied as foliar spraying $(n=3)$. Values denoted by the same letters in the concentrations do not differ statistically at $p<0.05$ 
Dry weight content of leaves of weeds was also evaluated in the present study. Soil application of QASs led to an increase in dry weight content in the leaves of G. parviflora and $R$. acetosa compared to the control. However, foliar spraying of the weeds resulted in an increase in leaf dry weight content only for $R$. acetosa, which increased in a dose dependent fashion. An increase in dry weight level in $C$. album leaves was only found following spraying with $1 \%$ and $2 \%$ solutions [TBA] $\left[\mathrm{PF}_{6}\right]$ (Fig. 2).

An increase in dry weight content in the plants coming into contact with chemicals, including QASs and ILs, was also reported by Biczak et al. (2015) and Matusiak et al. (2013). The results obtained by Liu et al. (2015a), are in contrast to the findings obtained in this study, since the authors observed a decrease in dry weight content in the leaves of broad bean under an influence of 1-butyl-3-methylimidazolium chloride. The discrepancy in the results of the research concerning chemicals effect on dry weight accumulation in plants may prove that the changes in dry weight content are related to, inter alia, species differences of the examined plants.

Changes in photosynthetic pigment content are among the most important biomarkers of oxidative stress in plants. Some authors (Ma et al. 2010; Zhang et al. 2013; Liu et al. 2015b; Herman et al. 1998; Wang et al. 2009) reported almost a linear decline in assimilation pigments with content with increasing levels of QAS or IL compounds in the soil. In the present experiment, the use of all QASs in the form of soil application and foliar spraying caused a reduction in the content of chlorophyll $a$, chlorophyll $b$, total chlorophyll and carotenoids in most of the examined weeds. In turn, soil treatments also resulted in a decline in the ratio of chlorophyll $a$ to $b$ in $R$. acetosa and G. apviflora, as well as a decrease in the ratio of total chlorophyll to carotenoids G. parviflora and C. album. No such relationships were observed with foliar treatment (Tables 1,2).

(a)

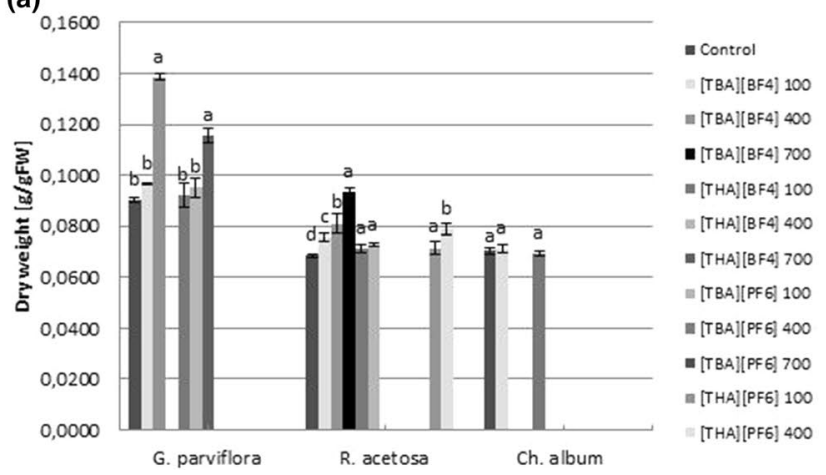

It has been reported that chemicals in the soil have caused oxidative stress in plants, and that overproduction of reactive oxygen species (ROS) can damage, inter alia, membranes of chloroplasts (Sun et al. 2007; Gengmao et al. 2015; Arias-Baldrich et al. 2015). This causes disorders in chlorophyll synthesis (mainly chlorophyll $a$ ) and premature plant aging. A decrease in the content of carotenoids found in this study, which are the primary line of defence of photosystems PSI and PSII against ROS, can also result in harmful effects of the examined QASs on the weeds (Biczak 2016; Biczak et al. 2016; Pawłowska and Biczak 2016).

In summary, $[\mathrm{TBA}]\left[\mathrm{BF}_{4}\right],[\mathrm{THA}]\left[\mathrm{BF}_{4}\right],[\mathrm{TBA}]\left[\mathrm{PF}_{6}\right]$ and $[\mathrm{THA}]\left[\mathrm{PF}_{6}\right]$ showed selective herbicidal properties for G. parviflora, C. album and R. acetosa. Phytotoxicity of QASs to the highest degree depended on the form of the applied treatment. The strongest herbicidal activity was found for the compounds applied to the soil in which the weed seeds were sown. However, no major changes in growth and development of the weeds were observed with spraying applications. With both forms of treatment, QAS effects were positively correlated with the concentration of the compound, i.e., higher concentrations resulted in greater effects. An important factor affecting the phytotoxicity of examined salts was also the type of anion and the length of alkyl substituent. Compounds showing higher toxic activity for weeds were QAS compounds with the $\mathrm{PF}_{6}{ }^{-}$anion. Also, higher phytotoxicity was observed for QAS compounds with substituents containing four carbon atoms. Moreover, an effect of the examined compounds depended on plant species. C. album was the most sensitive species, as evidenced by complete inhibition of shoot and root growth. The weeds in which changes in external appearance and an inhibition of growth and roots length were observed also showed changes in dry weight content. A decrease in levels of assimilation pigments was positively correlated

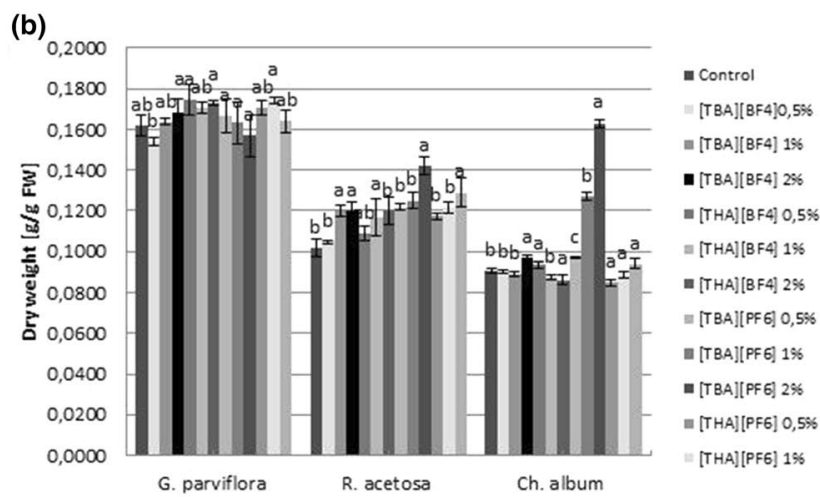

Fig. 2 Effect of $[\mathrm{TBA}]\left[\mathrm{BF}_{4}\right],[\mathrm{THA}]\left[\mathrm{BF}_{4}\right],[\mathrm{TBA}]\left[\mathrm{PF}_{6}\right]$ and $[\mathrm{THA}]\left[\mathrm{PF}_{6}\right]$ in soil (a) and spraying (b) on dry weight $\left(\mathrm{g} \mathrm{g}^{-1} \mathrm{FW}\right)$ weeds $($ mean $\pm \mathrm{SD}, \mathrm{n}=3$ ). Values denoted by the same letters in the concentrations do not differ statistically at $p<0.05$ 
Table 1 Effect of QAS compounds in soil on photosynthetic pigments in weed leaves (mean $\pm \mathrm{SD}, n=3$ ).

\begin{tabular}{|c|c|c|c|c|c|c|c|}
\hline \multirow{2}{*}{\multicolumn{2}{|c|}{$\begin{array}{l}\text { Concentration of QASs } \\
\left(\mathrm{mg} \mathrm{kg}^{-1} \text { soil DW) }\right.\end{array}$}} & \multicolumn{6}{|c|}{ Pigments (mg g $\left.{ }^{-1} \mathrm{FW}\right)$} \\
\hline & & Chla & Chl $b$ & Car & Chl $a+\mathrm{Chl} b$ & Chl $a / \mathrm{Chl} b$ & Chl $a+b /$ car \\
\hline \multicolumn{8}{|c|}{ Gallant soldier (Galinsoga parviflora Cav.) } \\
\hline & 0 & $1.090 \pm 0.035^{\mathrm{a}}$ & $0.344 \pm 0.007^{\mathrm{a}}$ & $0.265 \pm 0.008^{\mathrm{a}}$ & $1.434 \pm 0.038^{\mathrm{a}}$ & $3.166 \pm 0.092^{\mathrm{a}}$ & $5.419 \pm 0.015^{\mathrm{a}}$ \\
\hline \multirow[t]{3}{*}[\mathrm{TBA}]{$\left[\mathrm{BF}_{4}\right]$} & 100 & $1.015 \pm 0.028^{\mathrm{b}}$ & $0.322 \pm 0.007^{\mathrm{b}}$ & $0.255 \pm 0.007^{\mathrm{a}}$ & $1.337 \pm 0.035^{\mathrm{a}}$ & $3.147 \pm 0.029^{\mathrm{a}}$ & $5.241 \pm 0.040^{\mathrm{ab}}$ \\
\hline & 400 & $0.626 \pm 0.004^{\mathrm{c}}$ & $0.239 \pm 0.004^{\mathrm{c}}$ & $0.175 \pm 0.001^{\mathrm{b}}$ & $0.865 \pm 0.007^{\mathrm{b}}$ & $2.622 \pm 0.026^{\mathrm{b}}$ & $4.925 \pm 0.040^{\mathrm{b}}$ \\
\hline & 700 & - & - & - & - & - & - \\
\hline \multirow[t]{3}{*}[\mathrm{THA}]{$\left[\mathrm{BF}_{4}\right]$} & 100 & $1.070 \pm 0.016^{\mathrm{a}}$ & $0.332 \pm 0.006^{\mathrm{a}}$ & $0.261 \pm 0.005^{\mathrm{a}}$ & $1.402 \pm 0.023^{\mathrm{a}}$ & $3.220 \pm 0.016^{\mathrm{a}}$ & $5.369 \pm 0.025^{\mathrm{a}}$ \\
\hline & 400 & $0.895 \pm 0.012^{\mathrm{b}}$ & $0.306 \pm 0.001^{\mathrm{b}}$ & $0.228 \pm 0.003^{\mathrm{b}}$ & $1.201 \pm 0.013^{\mathrm{b}}$ & $2.922 \pm 0.029^{b}$ & $5.265 \pm 0.036^{\mathrm{a}}$ \\
\hline & 700 & $0.760 \pm 0.047^{\mathrm{c}}$ & $0.277 \pm 0.017^{\mathrm{b}}$ & $0.197 \pm 0.011^{\mathrm{c}}$ & $1.037 \pm 0.063^{\mathrm{c}}$ & $2.739 \pm 0.023^{\mathrm{c}}$ & $5.264 \pm 0.028^{\mathrm{a}}$ \\
\hline \multirow[t]{3}{*}[\mathrm{TBA}]{$\left[\mathrm{PF}_{6}\right]$} & 100 & - & - & - & - & - & - \\
\hline & 400 & - & - & - & - & - & - \\
\hline & 700 & - & - & - & - & - & - \\
\hline \multirow[t]{3}{*}[\mathrm{THA}]{$\left[\mathrm{PF}_{6}\right]$} & 100 & - & - & - & - & - & - \\
\hline & 400 & - & - & - & - & - & - \\
\hline & 700 & - & - & - & - & - & - \\
\hline \multicolumn{8}{|c|}{ Common sorrel (Rumex acetosa L.) } \\
\hline & 0 & $0.900 \pm 0.001^{\mathrm{a}}$ & $0.270 \pm 0.001^{\mathrm{a}}$ & $0.218^{\mathrm{a}}$ & $1.170 \pm 0.002^{\mathrm{a}}$ & $3.335 \pm 0.016^{\mathrm{a}}$ & $5.361 \pm 0.018^{\mathrm{a}}$ \\
\hline \multirow[t]{3}{*}[\mathrm{TBA}]{$\left[\mathrm{BF}_{4}\right]$} & 100 & $0.743 \pm 0.002^{b}$ & $0.236 \pm 0.002^{\mathrm{b}}$ & $0.181 \pm 0.001^{\mathrm{b}}$ & $0.979 \pm 0.004^{\mathrm{b}}$ & $3.142 \pm 0.015^{\mathrm{a}}$ & $5.409 \pm 0.024^{\mathrm{a}}$ \\
\hline & 400 & $0.737 \pm 0.005^{\mathrm{b}}$ & $0.230 \pm 0.006^{\mathrm{bc}}$ & $0.186 \pm 0.001^{\mathrm{b}}$ & $0.967 \pm 0.011^{\mathrm{b}}$ & $3.204 \pm 0.062^{\mathrm{a}}$ & $5.193 \pm 0.050^{\mathrm{a}}$ \\
\hline & 700 & $0.587^{\mathrm{c}}$ & $0.214 \pm 0.002^{c}$ & $0.169 \pm 0.002^{\mathrm{c}}$ & $0.801 \pm 0.001^{\mathrm{c}}$ & $2.748 \pm 0.023^{b}$ & $4.742 \pm 0.057^{\mathrm{b}}$ \\
\hline \multirow[t]{3}{*}[\mathrm{THA}]{$\left[\mathrm{BF}_{4}\right]$} & 100 & $0.774 \pm 0.007^{\mathrm{b}}$ & $0.242 \pm 0.003^{\mathrm{b}}$ & $0.185 \pm 0.001^{\mathrm{c}}$ & $1.016 \pm 0.010^{\mathrm{b}}$ & $3.195 \pm 0.016^{\mathrm{a}}$ & $5.481 \pm 0.052^{\mathrm{a}}$ \\
\hline & 400 & $0.754 \pm 0.021^{\mathrm{b}}$ & $0.269 \pm 0.009^{\mathrm{a}}$ & $0.199 \pm 0.006^{\mathrm{b}}$ & $1.023 \pm 0.030^{\mathrm{b}}$ & $2.807 \pm 0.030^{\mathrm{b}}$ & $5.134 \pm 0.012^{\mathrm{a}}$ \\
\hline & 700 & - & - & - & - & - & - \\
\hline \multirow[t]{3}{*}[\mathrm{TBA}]{$\left[\mathrm{PF}_{6}\right]$} & 100 & - & - & - & - & - & - \\
\hline & 400 & - & - & - & - & - & - \\
\hline & 700 & - & - & - & - & - & - \\
\hline \multirow[t]{3}{*}[\mathrm{THA}]{$\left[\mathrm{PF}_{6}\right]$} & 100 & $0.854 \pm 0.021^{\mathrm{a}}$ & $0.279 \pm 0.007^{\mathrm{a}}$ & $0.223 \pm 0.005^{\mathrm{a}}$ & $1.133 \pm 0.028^{\mathrm{a}}$ & $3.063 \pm 0.021^{\mathrm{b}}$ & $5.081 \pm 0.006^{\mathrm{a}}$ \\
\hline & 400 & $0.726 \pm 0.003^{b}$ & $0.218 \pm 0.006^{\mathrm{b}}$ & $0.187 \pm 0.004^{b}$ & $0.944 \pm 0.007^{\mathrm{b}}$ & $3.326 \pm 0.092^{\mathrm{a}}$ & $5.042 \pm 0.110^{\mathrm{a}}$ \\
\hline & 700 & - & - & - & - & - & - \\
\hline \multicolumn{8}{|c|}{ White goosefoot (Chenopodium album L.) } \\
\hline & 0 & $0.742 \pm 0.023^{\mathrm{a}}$ & $0.225 \pm 0.007^{\mathrm{a}}$ & $0.188 \pm 0.005^{\mathrm{a}}$ & $0.967 \pm 0.029^{\mathrm{a}}$ & $3.305 \pm 0.027^{\mathrm{a}}$ & $5.152 \pm 0.016^{\mathrm{a}}$ \\
\hline \multirow[t]{3}{*}[\mathrm{TBA}]{$\left[\mathrm{BF}_{4}\right]$} & 100 & $0.679 \pm 0.018^{\mathrm{b}}$ & $0.193 \pm 0.007^{\mathrm{b}}$ & $0.172 \pm 0.002^{\mathrm{b}}$ & $0.872 \pm 0.024^{b}$ & $3.520 \pm 0.031^{\mathrm{a}}$ & $5.072 \pm 0.078^{\mathrm{a}}$ \\
\hline & 400 & - & - & - & - & - & - \\
\hline & 700 & - & - & - & - & - & - \\
\hline \multirow[t]{3}{*}[\mathrm{THA}]{$\left[\mathrm{BF}_{4}\right]$} & 100 & $0.701 \pm 0.006^{\mathrm{a}}$ & $0.212 \pm 0.006^{\mathrm{a}}$ & $0.189 \pm 0.001^{\mathrm{a}}$ & $0.913 \pm 0.011^{\mathrm{a}}$ & $3.304 \pm 0.064^{\mathrm{a}}$ & $4.833 \pm 0.080^{\mathrm{b}}$ \\
\hline & 400 & - & - & - & - & - & - \\
\hline & 700 & - & - & - & - & - & - \\
\hline \multirow[t]{3}{*}[\mathrm{TBA}]{$\left[\mathrm{PF}_{6}\right]$} & 100 & - & - & - & - & - & - \\
\hline & 400 & - & - & - & - & - & - \\
\hline & 700 & - & - & - & - & - & - \\
\hline \multirow[t]{3}{*}[\mathrm{THA}]{$\left[\mathrm{PF}_{6}\right]$} & 100 & - & - & - & - & - & - \\
\hline & 400 & - & - & - & - & - & - \\
\hline & 700 & - & - & - & - & - & - \\
\hline
\end{tabular}

Values denoted by the same letters in the columns do not differ statistically at $p<0.05$

Chla chlorophyll $a$, Chlb chlorophyll $b$, Chla + Chlb chlorophyll $a+$ chlorophyll $b$, car carotenoides, Chla/Chlb chlorphyll $a /$ chlorophyll $b$, Chla + b/car (chlorophyll $a+$ chlorophyl $b$ )/carotenoides 
Table 2 Effect of QAS compounds sprayed with solutions on photosynthetic pigments in weed leaves (mean $\pm \mathrm{SD}, \mathrm{n}=3$ ).

\begin{tabular}{|c|c|c|c|c|c|c|c|}
\hline \multirow{2}{*}{\multicolumn{2}{|c|}{$\begin{array}{l}\text { Concentration of QASs } \\
\left(\mathrm{mg} \mathrm{kg}^{-1} \text { soil DW) }\right.\end{array}$}} & \multicolumn{6}{|c|}{ Pigments (mg g $\left.{ }^{-1} \mathrm{FW}\right)$} \\
\hline & & Chla & $\mathrm{Chl} b$ & Car & $\mathrm{Chl} a+\mathrm{Chl} b$ & Chla/Chl $b$ & Chl $a+b /$ car \\
\hline \multicolumn{8}{|c|}{ Gallant soldier (Galinsoga parviflora Cav.) } \\
\hline & 0 & $0.694 \pm 0.004^{\mathrm{b}}$ & $0.224 \pm 0.003^{\mathrm{b}}$ & $0.205 \pm 0.001^{\mathrm{b}}$ & $0.918 \pm 0.006^{\mathrm{b}}$ & $3.100 \pm 0.024^{\mathrm{b}}$ & $4.484 \pm 0.051^{\mathrm{a}}$ \\
\hline \multirow[t]{3}{*}[\mathrm{TBA}]{$\left[\mathrm{BF}_{4}\right]$} & 100 & $0.761 \pm 0.016^{\mathrm{a}}$ & $0.243 \pm 0.005^{\mathrm{a}}$ & $0.219 \pm 0.004^{\mathrm{a}}$ & $1.004 \pm 0.021^{\mathrm{a}}$ & $3.129 \pm 0.004^{\mathrm{b}}$ & $4.952 \pm 0.013^{\mathrm{a}}$ \\
\hline & 400 & $0.614 \pm 0.019^{c}$ & $0.180 \pm 0.006^{\mathrm{c}}$ & $0.178 \pm 0.004^{\mathrm{c}}$ & $0.794 \pm 0.014^{\mathrm{c}}$ & $3.421 \pm 0.211^{\mathrm{a}}$ & $4.460 \pm 0.015^{\mathrm{a}}$ \\
\hline & 700 & $0.607 \pm 0.009^{c}$ & $0.200 \pm 0.003^{c}$ & $0.187 \pm 0.002^{\mathrm{c}}$ & $0.807 \pm 0.012^{\mathrm{c}}$ & $3.044 \pm 0.009^{\mathrm{b}}$ & $4.304 \pm 0.026^{\mathrm{a}}$ \\
\hline \multirow[t]{3}{*}[\mathrm{THA}]{$\left[\mathrm{BF}_{4}\right]$} & 100 & $0.688 \pm 0.016^{\mathrm{a}}$ & $0.231 \pm 0.008^{\mathrm{a}}$ & $0.212 \pm 0.004^{\mathrm{a}}$ & $0.919 \pm 0.024^{\mathrm{a}}$ & $2.982 \pm 0.039^{\mathrm{b}}$ & $4.339 \pm 0.045^{\mathrm{ab}}$ \\
\hline & 400 & $0.597 \pm 0.020^{\mathrm{b}}$ & $0.182 \pm 0.009^{\mathrm{b}}$ & $0.182 \pm 0.006^{\mathrm{b}}$ & $0.779 \pm 0.030^{\mathrm{b}}$ & $3.277 \pm 0.062^{\mathrm{a}}$ & $4.284 \pm 0.032^{\mathrm{ab}}$ \\
\hline & 700 & $0.555 \pm 0.013^{\mathrm{b}}$ & $0.183 \pm 0.006^{\mathrm{b}}$ & $0.179 \pm 0.004^{\mathrm{b}}$ & $0.739 \pm 0.019^{\mathrm{b}}$ & $3.034 \pm 0.029^{\mathrm{ab}}$ & $4.120 \pm 0.022^{\mathrm{b}}$ \\
\hline \multirow[t]{3}{*}[\mathrm{TBA}]{$\left[\mathrm{PF}_{6}\right]$} & 100 & $0.606 \pm 0.002^{\mathrm{b}}$ & $0.204 \pm 0.001^{\mathrm{b}}$ & $0.184 \pm 0.001^{\mathrm{b}}$ & $0.810 \pm 0.003^{\mathrm{b}}$ & $2.966 \pm 0.010^{\mathrm{a}}$ & $4.411 \pm 0.018^{\mathrm{a}}$ \\
\hline & 400 & $0.607 \pm 0.007^{\mathrm{b}}$ & $0.206 \pm 0.004^{\mathrm{b}}$ & $0.183 \pm 0.002^{\mathrm{b}}$ & $0.813 \pm 0.011^{\mathrm{b}}$ & $2.954 \pm 0.037^{\mathrm{a}}$ & $4.435 \pm 0.037^{\mathrm{a}}$ \\
\hline & 700 & $0.580 \pm 0.008^{\mathrm{b}}$ & $0.195 \pm 0.004^{\mathrm{b}}$ & $0.179 \pm 0.002^{\mathrm{b}}$ & $0.775 \pm 0.012^{\mathrm{b}}$ & $2.968 \pm 0.020^{\mathrm{a}}$ & $4.339 \pm 0.028^{\mathrm{a}}$ \\
\hline \multirow[t]{3}{*}[\mathrm{THA}]{$\left[\mathrm{PF}_{6}\right]$} & 100 & $0.580 \pm 0.006^{\mathrm{b}}$ & $0.198 \pm 0.001^{\mathrm{b}}$ & $0.180 \pm 0.002^{\mathrm{b}}$ & $0.778 \pm 0.005^{\mathrm{b}}$ & $2.933 \pm 0.036^{\mathrm{b}}$ & $4.326 \pm 0.026^{\mathrm{ab}}$ \\
\hline & 400 & $0.464 \pm 0.005^{\mathrm{c}}$ & $0.157 \pm 0.002^{\mathrm{c}}$ & $0.154 \pm 0.001^{\mathrm{c}}$ & $0.620 \pm 0.005^{\mathrm{c}}$ & $2.957 \pm 0.049^{\mathrm{b}}$ & $4.041 \pm 0.030^{\mathrm{b}}$ \\
\hline & 700 & $0.422 \pm 0.010^{\mathrm{c}}$ & $0.124 \pm 0.003^{\mathrm{d}}$ & $0.138 \pm 0.004^{\mathrm{d}}$ & $0.546 \pm 0.013^{\mathrm{d}}$ & $3.406 \pm 0.042^{\mathrm{a}}$ & $3.969 \pm 0.028^{\mathrm{b}}$ \\
\hline \multicolumn{8}{|c|}{ Common sorrel (Rumex acetosa L.) } \\
\hline & 0 & $0,843 \pm 0.007^{\mathrm{a}}$ & $0.260 \pm 0.003^{\mathrm{b}}$ & $0.207 \pm 0.002^{\mathrm{b}}$ & $1,103 \pm 0.005^{\mathrm{a}}$ & $3.236 \pm 0.058^{\mathrm{a}}$ & $5.319 \pm 0.053^{\mathrm{a}}$ \\
\hline \multirow[t]{3}{*}[\mathrm{TBA}]{$\left[\mathrm{BF}_{4}\right]$} & 100 & $0.839 \pm 0.004^{\mathrm{a}}$ & $0.277 \pm 0.001^{\mathrm{a}}$ & $0.226 \pm 0.001^{\mathrm{a}}$ & $1.116 \pm 0.005^{\mathrm{a}}$ & $3.034 \pm 0.008^{\mathrm{ab}}$ & $4.926 \pm 0.013^{\mathrm{ab}}$ \\
\hline & 400 & $0.769 \pm 0.006^{\mathrm{b}}$ & $0.258 \pm 0.005^{\mathrm{b}}$ & $0.205 \pm 0.003^{b}$ & $1.027 \pm 0.003^{\mathrm{b}}$ & $2.983 \pm 0.078^{\mathrm{b}}$ & $5.019 \pm 0.048^{\mathrm{ab}}$ \\
\hline & 700 & $0.673 \pm 0.001^{\mathrm{c}}$ & $0.231 \pm 0.002^{\mathrm{c}}$ & $0.187 \pm 0.001^{\mathrm{c}}$ & $0.904 \pm 0.003^{\mathrm{c}}$ & $2.914 \pm 0.026^{\mathrm{b}}$ & $4.845 \pm 0.035^{\mathrm{a}}$ \\
\hline \multirow[t]{3}{*}[\mathrm{THA}]{$\left[\mathrm{BF}_{4}\right]$} & 100 & $0.736 \pm 0.002^{\mathrm{b}}$ & $0.236 \pm 0.002^{\mathrm{b}}$ & $0.202 \pm 0.001^{\mathrm{a}}$ & $0.972 \pm 0.002^{\mathrm{b}}$ & $3.121 \pm 0.026^{\mathrm{ab}}$ & $4.822 \pm 0.026^{\mathrm{b}}$ \\
\hline & 400 & $0.699 \pm 0.011^{\mathrm{b}}$ & $0.233 \pm 0.008^{\mathrm{b}}$ & $0.184 \pm 0.004^{\mathrm{b}}$ & $0.931 \pm 0.005^{\mathrm{b}}$ & $3.006 \pm 0.146^{\mathrm{b}}$ & $5.050 \pm 0.084^{\mathrm{ab}}$ \\
\hline & 700 & $0.636 \pm 0.006^{\mathrm{c}}$ & $0.194 \pm 0.003^{c}$ & $0.171^{\mathrm{b}}$ & $0.830 \pm 0.009^{c}$ & $3.283 \pm 0.030^{\mathrm{a}}$ & $4.863 \pm 0.048^{\mathrm{b}}$ \\
\hline \multirow[t]{3}{*}[\mathrm{TBA}]{$\left[\mathrm{PF}_{6}\right]$} & 100 & $0.672 \pm 0.054^{\mathrm{b}}$ & $0.216 \pm 0.018^{\mathrm{b}}$ & $0.178 \pm 0.015^{\mathrm{b}}$ & $0.888 \pm 0.072^{\mathrm{b}}$ & $3.111 \pm 0.007^{\mathrm{ab}}$ & $4.979 \pm 0.019^{\mathrm{ab}}$ \\
\hline & 400 & $0.661 \pm 0.021^{\mathrm{b}}$ & $0.221 \pm 0.008^{\mathrm{b}}$ & $0.182 \pm 0.006^{\mathrm{b}}$ & $0.882 \pm 0.030^{\mathrm{b}}$ & $2.992 \pm 0.019^{\mathrm{b}}$ & $4.848 \pm 0.042^{\mathrm{b}}$ \\
\hline & 700 & $0.689 \pm 0.004^{\mathrm{b}}$ & $0.213 \pm 0.004^{\mathrm{b}}$ & $0.184 \pm 0.006^{\mathrm{b}}$ & $0.901 \pm 0.006^{\mathrm{b}}$ & $3.242 \pm 0.067^{\mathrm{a}}$ & $4.892 \pm 0.129^{\mathrm{b}}$ \\
\hline \multirow[t]{3}{*}[\mathrm{THA}]{$\left[\mathrm{PF}_{6}\right]$} & 100 & $0.767 \pm 0.002^{\mathrm{b}}$ & $0.254 \pm 0.001^{\mathrm{a}}$ & $0.200 \pm 0.001^{\mathrm{a}}$ & $1.021 \pm 0.002^{\mathrm{b}}$ & $3.024 \pm 0.016^{\mathrm{a}}$ & $5.098 \pm 0.027^{\mathrm{a}}$ \\
\hline & 400 & $0.765 \pm 0.005^{\mathrm{b}}$ & $0.247 \pm 0.002^{\mathrm{a}}$ & $0.199 \pm 0.003^{\mathrm{a}}$ & $1.012 \pm 0.004^{\mathrm{b}}$ & $3.094 \pm 0.046^{\mathrm{a}}$ & $5.076 \pm 0.095^{\mathrm{a}}$ \\
\hline & 700 & $0.694 \pm 0.017^{\mathrm{c}}$ & $0.246 \pm 0.008^{\mathrm{a}}$ & $0.186 \pm 0.002^{\mathrm{b}}$ & $0.940 \pm 0.025^{\mathrm{c}}$ & $2.828 \pm 0.020^{\mathrm{b}}$ & $5.053 \pm 0.182^{\mathrm{a}}$ \\
\hline \multicolumn{8}{|c|}{ White goosefoot (Chenopodium album L.) } \\
\hline & 0 & $1.259 \pm 0.012^{\mathrm{a}}$ & $0.336 \pm 0.005^{\mathrm{a}}$ & $0.303 \pm 0.003^{\mathrm{a}}$ & $1.595 \pm 0.018^{\mathrm{a}}$ & $3.743 \pm 0.027^{\mathrm{a}}$ & $5.268 \pm 0.016^{\mathrm{a}}$ \\
\hline \multirow[t]{3}{*}[\mathrm{TBA}]{$\left[\mathrm{BF}_{4}\right]$} & 100 & $1.133 \pm 0.005^{\mathrm{b}}$ & $0.306 \pm 0.002^{\mathrm{b}}$ & $0.287 \pm 0.001^{\mathrm{ab}}$ & $1.439 \pm 0.007^{\mathrm{b}}$ & $3.708 \pm 0.017^{\mathrm{a}}$ & $5.011 \pm 0.038^{\mathrm{a}}$ \\
\hline & 400 & $1.085 \pm 0.019^{\mathrm{b}}$ & $0.288 \pm 0.007^{\mathrm{c}}$ & $0.274 \pm 0.005^{\mathrm{b}}$ & $1.373 \pm 0.026^{\mathrm{b}}$ & $3.771 \pm 0.028^{\mathrm{a}}$ & $5.015 \pm 0.016^{\mathrm{a}}$ \\
\hline & 700 & $0.889 \pm 0.005^{\mathrm{c}}$ & $0.235 \pm 0.002^{\mathrm{d}}$ & $0.228 \pm 0.004^{c}$ & $1.124 \pm 0.006^{\mathrm{c}}$ & $3.778 \pm 0.021^{\mathrm{a}}$ & $4.926 \pm 0.091^{\mathrm{a}}$ \\
\hline \multirow[t]{3}{*}[\mathrm{THA}]{$\left[\mathrm{BF}_{4}\right]$} & 100 & $1.093 \pm 0.006^{\mathrm{b}}$ & $0.300 \pm 0.001^{\mathrm{b}}$ & $0.268 \pm 0.003^{b}$ & $1.393 \pm 0.005^{\mathrm{b}}$ & $3.649 \pm 0.026^{\mathrm{a}}$ & $5.189 \pm 0.031^{\mathrm{a}}$ \\
\hline & 400 & $1.021 \pm 0.006^{\mathrm{bc}}$ & $0.276 \pm 0.005^{\mathrm{bc}}$ & $0.254 \pm 0.001^{\mathrm{b}}$ & $1.298 \pm 0.011^{\mathrm{bc}}$ & $3.700 \pm 0.044^{\mathrm{a}}$ & $5.108 \pm 0.041^{\mathrm{a}}$ \\
\hline & 700 & $0.967 \pm 0.033^{c}$ & $0.261 \pm 0.012^{\mathrm{c}}$ & $0.247 \pm 0.008^{\mathrm{b}}$ & $1.228 \pm 0.045^{\mathrm{c}}$ & $3.708 \pm 0.048^{\mathrm{a}}$ & $4.963 \pm 0.033^{\mathrm{a}}$ \\
\hline \multirow[t]{3}{*}[\mathrm{TBA}]{$\left[\mathrm{PF}_{6}\right]$} & 100 & $1.026 \pm 0.025^{\mathrm{b}}$ & $0.292 \pm 0.011^{\mathrm{b}}$ & $0.242 \pm 0.006^{\mathrm{b}}$ & $1.318 \pm 0.034^{\mathrm{b}}$ & $3.522 \pm 0.067^{\mathrm{a}}$ & $5.454 \pm 0.061^{\mathrm{a}}$ \\
\hline & 400 & $0.850 \pm 0.006^{\mathrm{c}}$ & $0.256 \pm 0.004^{c}$ & $0.209 \pm 0.001^{\mathrm{c}}$ & $1.106 \pm 0.009^{c}$ & $3.321 \pm 0.032^{\mathrm{b}}$ & $5.291 \pm 0.026^{\mathrm{a}}$ \\
\hline & 700 & $0.789 \pm 0.005^{\mathrm{c}}$ & $0.230 \pm 0.004^{\mathrm{d}}$ & $0.196 \pm 0.001^{\mathrm{c}}$ & $1.019 \pm 0.009^{\mathrm{c}}$ & $3.431 \pm 0.035^{\mathrm{ab}}$ & $5.212 \pm 0.037^{\mathrm{a}}$ \\
\hline \multirow[t]{3}{*}[\mathrm{THA}]{$\left[\mathrm{PF}_{6}\right]$} & 100 & $1.195 \pm 0.011^{\mathrm{b}}$ & $0.308 \pm 0.003^{\mathrm{b}}$ & $0.258 \pm 0.003^{b}$ & $1.503 \pm 0.014^{\mathrm{ab}}$ & $3.881 \pm 0.010^{\mathrm{a}}$ & $5.826 \pm 0.019^{\mathrm{a}}$ \\
\hline & 400 & $1.206 \pm 0.043^{\mathrm{b}}$ & $0.332 \pm 0.012^{\mathrm{a}}$ & $0.268 \pm 0.009^{b}$ & $1.539 \pm 0.055^{\mathrm{a}}$ & $3.631 \pm 0.002^{\mathrm{a}}$ & $5.736 \pm 0.028^{\mathrm{a}}$ \\
\hline & 700 & $1.109 \pm 0.013^{\mathrm{c}}$ & $0.308 \pm 0.004^{\mathrm{b}}$ & $0.255 \pm 0.003^{\mathrm{b}}$ & $1.416 \pm 0.017^{\mathrm{b}}$ & $3.604 \pm 0.013^{\mathrm{a}}$ & $5.555 \pm 0.021^{\mathrm{ab}}$ \\
\hline
\end{tabular}

Values denoted by the same letters in the columns do not differ statistically at $p<0.05$

Chla chlorophyll $a$, Chlb chlorophyll $b$, Chla + Chlb chlorophyll $a+$ chlorophyll $b$, car carotenoides, Chla/Chlb chlorphyll $a /$ chlorophyll $b$, Chla $+b / c a r$ (chlorophyll $a+$ chlorophyl $b$ )/carotenoides 
with an increase in QAS concentration in the soil or in the spray solution.

Acknowledgements The work was financed by a statutory activity subsidy from the Polish Ministry of Science and Higher Education for The Faculty of Environmental Management and Agriculture of West Pomeranian University of Technology in Szczecin and The Faculty of Mathematics and Natural Sciences of Jan Długosz University in Częstochowa.

Open Access This article is distributed under the terms of the Creative Commons Attribution 4.0 International License (http:// creativecommons.org/licenses/by/4.0/), which permits unrestricted use, distribution, and reproduction in any medium, provided you give appropriate credit to the original author(s) and the source, provide a link to the Creative Commons license, and indicate if changes were made.

\section{References}

Arias-Baldrich C, Bosch N, Begines D, Feria AB, Monreal JA, García-Mauriño S (2015) Proline synthesis in barley under iron deficiency and salinity. J Plant Physiol 183:121-129

Biczak R (2016) Quaternary ammonium salts with tetrafluoroborate anion: phytotoxicity and oxidative stress in terrestrial plants. J Hazard Mater 304:173-185

Biczak R, Pawłowska B, Bałczewski P, Rychter P (2014) The role of the anion in the toxicity of imidazolium ionic liquids. J Hazard Mater 274:181-190

Biczak R, Pawłowska B, Feder-Kubis J (2015) The phytotoxicity of ionic liquids from natural pool of (-)-menthol with tetrafluoroborate anion. Environ Sci Pollut Res 22:11740-11754

Biczak R, Telesiński A, Pawłowska B (2016) Oxidative stress in spring barley and common radish exposed to quaternary ammonium salts with hexafluorophosphate anion. Plant Physiol Biochem 107:248-256

Chapman N, Miller AJ, Lindsey K, Whalley WR (2012) Roots, water, and nutrient acquisition: let's get physical. Trends Plant Sci 17:701-710

Cho Ch-W, Pham TPT, Jeon Y-Ch, Yun Y-S (2008) Influence of anions on the ionic liquids to a phytoplankton Selenastrum capricornutum. Green Chem 10:67-72

Gengmao Z, Yu H, Xing S, Shihui L, Quanmei S, Changhai W (2015) Salinity stress increases secondary metabolites and enzyme activity in safflower. Ind Crops Prod 64:175-181

Grabińska-Sota E (2004) Assessment of the impact of quaternary ammonium salts on the aquatic environment. Zesz Nauk Politech Śląsk, Gliwice, Poland (in Polish)

Herman B, Biczak R, Gurgul E (1998) Effect of 1,10-phenanthroline on peroxidase and catalase activity and chlorophyll, sugar, and ascorbic acid contents. Biol Plant 41:607-611
Kowalska I (2004) The content of selected components of spinach (Spinacia oleracea L.) grown at varying levels of calcium. Rocz Akad Roln, Poznań, pp 105-110

Liu H, Zhang S, Zhang X, Chen C (2015a) Growth inhibition and effect on photosystem by three imidazolium ionic liquids in rice seedlings. J Hazard Mater 286:440-448

Liu T, Zhu L, Wang J, Wang J, Xie H (2015b) The genotoxic and cytotoxic effects of 1-butyl-3-methylimidazolium chloride in soil on Vicia faba seedlings. J Hazard Mater 285:27-36

Ma J-M, Cai L-L, Zhang B-J, Hu L-W, Li X-Y, Wang J-J (2010) Acute toxicity and effects of 1-alkyl-3-methylimidazolium bromide ionic liquids on green algae. Ecotoxicol Environ Saf 73:1465-1469

Matusiak A, Lewkowski J, Rychter P, Biczak R (2013) Phytotoxicity of new furan-derived aminophosphonic acid, $\mathrm{N}$-aryl furaldimines and 5-nitrofuraldimine. J Agric Food Chem 61:7673-7678

Matzke M, Stolte S, Thiele K, Juffernholz T, Arning J, Ranke J., Welz-Biermann U, Jastorff B (2007) The influence of anion species on the toxicity of 1-alkyl-3-methylimidazolium ionic liquids observed in an (eco)toxicological test battery. Green Chem 9:1198-1207

Niemczak M, Giszter R, Czerniak K, Marcinkowska K, Walkiewicz F (2015) Bis(ammonium) ionic liquids with herbicidal anions. RSC Adv 5:15487-15493

Oren R, Werk KS, Buchmann N, Zimmermann R (1993) Chlorophyllnutrient relationships identify nutritionally caused decline in Picea abies stands. Can J For Res 23:1187-1195

Pawłowska B, Biczak R (2016) Evaluation of the effect of tetraethylammonium bromide and chloride on the growth and development of terrestrial plants. Chemosphere 149:24-33

Peric B, Sierra J, Martí E, Cruañas R, Garau MA (2014) A comparative study of the terrestrial ecotoxicity of selected protic and aprotic ionic liquids. Chemosphere 108:418-425

Pernak J, Niemczak M, Materna K, Żelechowski K, Marcinkowska K, Praczyk T (2016) Synthesis, properties and evaluation of biological activity of herbicidal ionic liquids with 4-(4-chloro-2-methylphenoxy)butanoate anion. RSC Adv 6:7330-7338

Praczyk T, Skrzypczak G (2004) Herbicides. Państwowe Wydawnictwo Rolnicze i Leśne, Poznań

Sun B, Jing Y, Chen K, Song L, Chen F, Zhang L (2007) Protective effect of nitric oxide on iron deficiency-induced oxidative stress in maize (Zea mays). J Plant Physiol 164:536-543

Telesiński A, Śnioszek M (2009) Bioindicators of environmental pollution with fluorine. Bromat Chem Toksykol 4:1148-1154

Travlos IS, Lysandrou M, Apostolidis V (2014) Efficacy of the herbicide GF-2581 (penoxsulam + florasulam) against broadleaf weeds in olives. Plant Soil Environ 12:574-579

Wang L-S, Wang L, Wang L, Wang G, Li Z-H, Wang J-J (2009) Effect of 1-butyl-3-methylimidazolium tetrafluoroborate on the wheat (Triticum aestivum L.) seedlings. Environ Toxicol 24:296-303

Zhang B, Li X, Chen D, Wang J (2013) Effects of 1-octyl-3-methylimidazolium bromide on the antioxidant system of Lemna minor. Protoplasma 250:103-110 